\title{
AFTER BRANDI - UMBERTO BALDINI AND THE MODERN THEORY OF CONSERVATION-RESTORATION IN ITALY
}

\section{BONSANTI Giorgio ${ }^{1}$}

\footnotetext{
${ }^{1}$ Former Professor of the State University of Florence (he held a chair on history and theory of conservation) and former Soprintendente (President-director) of the Opificio delle Pietre Dure - Laboratori di Restauro di Firenze; g.bonsanti44@gmail.com

https://orcid.org/0000-0003-2354-5954
}

ABSTRACT: Giorgio Bonsanti, as a contemporary witness of Umberto Baldini's professional activities in Florence and his successor as Soprintendente of the Opificio delle Pietre Dure, gives an overview of the closely intertwined situation in theory and practice of conservation-restoration at Baldini's time. He analyses terms and principles of Baldini's Theory and Methodological Unity and emphasises this theory as well as the related methods of reintegration as a development of Brandi's Theory and the methods of the Istituto Centrale per il Restauro in Rome. Furthermore, he shortly outlines actual Italian positions in theory and practice of conservation-restoration.

KEYWORDS: Italian Theories of Conservation-Restoration, Methodology of Conservation-Restoration, Italian Re-integration Methods, Theory and Practice of Conservation-Restoration

Cesare Brandi's Teoria del Restauro was first published in 1963, its second edition in 1977 (Brandi, 1963; Brandi, 1977). Umberto Baldini's Teoria del restauro e unità di metodologia was published in two volumes, the first in 1978 and the second in 1981 (Baldini, 1978; Baldini, 1981). Curiously, both Brandi and Baldini were 57 at the time of their theories. Umberto Baldini was born in the ancient Etruscan town of Pitigliano, in Southern Tuscany, in 1921; he died in 2006, aged eightyfive (Martusciello, 2013). An art historian, he had studied Pre-romanesque and Romanesque architecture with Mario Salmi and had taken his degree at the University of Florence in 1948. Very soon he started working at the Laboratorio di Restauro of the Soprintendenza, founded by Ugo Procacci in 1932. Baldini always remained involved in restoration, becoming the first Soprintendente of the newly born (1975) Opificio delle Pietre Dure, as a result of the merging of the Soprintendenza's restoration laboratory with other restoration centres existing in Florence. This solution was planned after the flood of 1966 as the most advisable for meeting the enormous problems arisen in the conservation of the cultural patrimony because of this catastrophic event. 
Baldini was also Director of the Istituto Centrale del Restauro in Rome from 1983 to 1987, when he retired from his career in the Ministero dei Beni Culturali, a denomination which we could translate as Ministry of Cultural Affairs, or Cultural Patrimony or Heritage. In the years after his retirement, he was involved in major projects of restoration, still very participant and active in the Italian scenery of conservation. I met him when still a student, in June 1966, when the Soprintendente Ugo Procacci, after taking a class on the History and Theory of Restoration at the University of Florence, of which I had edited the notes, put me to work with Baldini and with Baldini's lifelong friend and working companion Luciano Berti, later Director of the Uffizi and Soprintendente in Florence. This happened while preparing a new edition of the exhibitions of detached mural paintings which had been held periodically in Florence after the second World War and had become very popular. After that exhibition in 1966, of which no catalogue appeared because of the flood which came soon thereafter, I always kept contact with Baldini, more or less closely; actually in a conference on lacunae held at the Salone del Restauro di Ferrara in 2002 (see: Lacuna, 2009), he pronounced me in front of the audience as "il mio vero successore", my true successor; and here let me recall that I have been, first, director of the Ufficio Restauri of the Soprintendenza in Florence from 1979 to 1988, and afterwards, Soprintendente of the Opificio from 1988 to 2000. This last statement only to confirm that my familiarity with Baldini was very close and went on for forty years. When on December 14, 2011, a study day on Baldini was held at the Biblioteca degli Uffizi, I was entrusted with the task of dealing with Baldini as a theorist of conservation (Bonsanti, 2013a); and here I shall acknowledge that other times I have been allotted easier commitments. Colleagues from various Universities (my job at that time in my working career) openly questioned that one could speak of Baldini as a theorist, in spite of his Theory of Restoration having been the only one in Italy after Brandi, written by an art historian (meaning by that, not by an architect), to be published with the explicit declaration of being a "Theory" proclaimed in its title. Now, if I must try and consider once again this subject (Baldini the theorist), about which I am not sure I have reached a definitive convincement myself, I must emphasize as a first point that Baldini was, no question about that, a formidable "animale da restauro", as I called him on that first occasion. I wouldn't know how to translate this definition from Italian, but I trust it's clear enough; its sense is that he was unquestionably born with the mission and destiny to devote his life to restoration. Baldini has been enormously influential in the Italian milieu of restoration for practical reasons: by creating the modern Opificio, by establishing science as an indispensable partner in the conservation process, and by giving birth to the second national (State owned) School of restoration at the Opificio, after that of the Istituto Centrale per il Restauro in Rome. Baldini promoted fundamental exhibitions, such as Firenze Restaura - Il Laboratorio nel suo quarantennio, in 1972, and Metodo e Scienza Operatività e Ricerca nel Restauro, in 1982. On the other hand, I shall not omit that his brilliant achievements came sometimes together with little patience for administrative details, so that those who came after him (for instance, myself) had sooner or later to take care of some preexisting problems, in order to ensure that in a given institution its internal structure would also be effective for the future, independently from the physical persons who ran the Institute at that point. 
Now, a question which I left substantially unanswered in my contribution from 2011 is whether Baldini's Theory preceded or followed his practice; in other words, whether the solutions he had applied to restoration problems, came as a result of his theoretical thought, or rather his theory came as an aftermath of the actual intervention, a deduction of some sort. On second thought, probably this question is ill stated, the two stages came intertwined and inseparable. A comparison which I deem instructive for me, to be understood by myself still before than by others, can be made with attribution, that operation which is typical for an art historian. Does an attribution come as a result of an analytical process, or does it respond to an immediate, almost instinctive reaction, which one corroborates afterwards establishing the proper net of connections? (Bonsanti, 2013b) But after all, this question pertains only to the person who is the active subject of this operation; because for all others, what is relevant is not the mechanism as much as the result, that is, whether the attribution is right or is not. And restoration in Florence in the Baldini years, if I set myself in a historical and objective perspective, which I must say I do because I am in no way a chauvinist and I always felt being a citizen of the world, has proven highly successful and effective, with a huge amount of brilliant methodological and technical results. But, what about Baldini's Theory, at this point? His text, as far as I know, unlike Brandi's, has never been translated ${ }^{1}$, and I am afraid that a foreign reader would find access to it hard enough. Some factors concur: a prose which quite often proves tough reading (I counted a sentence of 39 lines), and the fact that Baldini made use of a very personal lexicon, based on terms which he had created himself, to which as a consequence one must get accustomed, take it or leave it, in order to proceed with his reading. Baldini's way of writing also makes use of a large number of inverted commas applied to plain words, with no apparent reason, keeping the reader wondering whether there's something there that he/she doesn't catch. Baldini's Theory anyway continues Brandi's, there is no contraposition, a fact that hasn't been understood by Brandi's exegetes from his Roman environment (see for instance: Cordaro, 2009, p. 23). Baldini adopts Brandi's recognition of three times in the life of an art work ("atto primo, secondo e terzo"), that is: creation, passage of time, and present moment (resulting in restoration); and emphasizes the concept of restoration as an act of critical philology. Lacunae are to be evaluated according to their "quantitä", quantity, and "modo", manner, resulting in their "peso", weight. He describes two sorts of lacunae, "lacuna perdita" (total loss of the image, or parts of an image) and "lacuna mancanza" (that is, something lacking, such as an abrasion or partial damage to a surface). In the first case, he elaborated the technical-optical solution named "astrazione cromatica", in the second, the so-called "selezione cromatica". In doing this, he also relied on the inputs coming from the restorer Ornella Casazza (Baldini's second wife), author herself of the book Il restauro pittorico nell'unità di Metodologia (Casazza,1981). I shall not dwell longer on this point, except for mentioning that while "astrazione cromatica" (not yet fully achieved on Cimabue's Crucifix, unlike what is commonly believed; it was perfected somewhat later) has not met wide consensus, "selezione cromatica" has become in Italy a very popular way of

Only a few lines were translated in: Stanley-Price, N., Kirby Talley Jr., M. \& Melucco Vaccaro, A. (1996). Reading in Conservation. Historical and Philosophical Issues on the Conservation of Cultural Heritage (pp. 355-357). Los Angeles: The Getty Conservation Institute. 
executing pictorial restoration ("restauro pittorico", "ritocco"). In fact, I have steadily insisted that "selezione cromatica" is not "another way" for filling lacunae, as the Roman school has it, but a natural development and perfecting of Brandi's "tratteggio", widely known as "rigatino". Baldini wrote at length about the act of "manutenzione", maintenance, a term bearing for him a wider meaning than usual: almost all restorations are "manutenzioni", and the word can also define, for instance, the rebuilding of an important architectural component of a wider context, such as the bell-tower of Piazza San Marco in Venice, newly erected in its former shape after the unforeseen collapse in 1902. Baldini as well as Brandi devoted some space to questions of architectural conservation, but unmistakably this was not their personal cup of tea, in this matter neither did they have a true interest nor sufficient competence and knowledge (Baldini more than Brandi, anyway). Characteristically enough, Baldini added to the title of his Theory the specification that he would also be dealing with "Unità di metodologia", methodological unity, meaning that his Theory would be extensible to all arts. He aptly insisted that a restored art work must be related to some surroundings, which called for a series of measures; so that on the whole we can say that he was rather an "interventista", that is, in favour of meaningful (I am not saying "heavy") completions and newly created collateral parts in order to place an art work in a proper setting. I underscore that this sort of solution is theoretically more admissible, in the Italian tradition, by having the added parts made differently from the original in some way, so that they become easily recognisable; a choice on the other hand which is not always feasible nor advisable in architecture, as Baldini himself knew. It remains to be pointed out, in this extremely succinct résumé of his thought ${ }^{2}$, that very interestingly he devoted himself in the Theory's second book to creating a sort of objective system for cleaning a painted surface, or rather, as I prefer to say, for removing unwanted substances from it. He did that by resorting to mathematical relationships between the various areas, a sort of equations; the idea was to demonstrate through the objectivity of numbers, the correctness of the traditional Italian approach to the cleaning of polychromies, done with careful awareness of the different degree of alterations of the single zones.

Now, looking back to Brandi's and Baldini's Theories, what strikes me as odd is how they did not seem to consider what was new that had appeared in Italy in the field of protection and safeguard of cultural patrimony. In 1965, the voluminous Proceedings of a Ministerial Commission (the so-called Commissione Franceschini) had been published, which officially introduced in the Italian culture the term and concept of "Bene Culturale", cultural goods or patrimony or asset; whatever the name, the idea was to comprise among the objects deserving public attention, all those which could be the subject of an interest of any kind shared by a community; that is, not only "opere d'arte", works of art, but also those of historical, anthropological, documentary importance as well. No trace of this relevant step towards modernity is to be found in Brandi's famous definition of conservation, which he repeated in 1977, that restoration exists if and when one has been able to recognize an object as a work of art, and that restoration is based on the item it applies to; nor did Baldini seem to care about that as well. So goes Brandi: Restoration consists

For an excellent statement on Baldini's theory, see: Ciatti, 2009, pp. 381-387. 
of the methodological moment in which the work of art is recognised, in its physical being, and in its dual aesthetic and historical nature, in view of its transmission to the future (Brandi, 2005, p. 48); which, if one reads carefully, does not by all means imply that a real act of restoration is actually carried out. I myself have suggested a different approach (2004, published 2006, see: Bonsanti, 2006) where it is precisely the performer of the act of conservation who determines whether what he is doing can be described as restoration. Paradoxically, according to this manner of dealing with the problem, one has restoration if what is done, is done by a restorer; so that the basic question does not concern the object as much as the subject. Briefly said this is my definition: Restoration is an activity aimed to the transmission to the future of a cultural property so as to maintain its existence and ensure its fruition, respecting its particular identity (a sum of originality plus integrity), and inside a multidisciplinary project of conservation. Restoration consists in a material operation, requesting a specific professionalism obtained through a dedicated formative process, so as to provide adequate capacity both of programming as of manually performing an intervention (Bonsanti, 2006, p. 67) ${ }^{3}$. But my time is running short, and to speak about the further developments of the theory, or theories, in conservation in Italy would call for at least another paper, so that I postpone this to a future occasion. Let me just point out to the existence, for instance, of recent studies on the theory of conservation of contemporary art. I only need still to make two points. The first: theories are to be found also where one does not expressly read the word "theory" in their title, so that for the elaboration of methodological concepts one should rather turn to many other sorts of printed pages. I am thinking of the concepts of minimal intervention, retreatability or repeatability, and of my personally favourite compatibility (of all kinds: chemical, physical, mechanical, aesthetical, historical). All these concepts are a huge part of the issues treated in conferences promoted by the most influential professional Italian associations, such as Arcadia Ricerche, for the yearly meetings in Bressanone, South Tyrol, called "Scienza e Beni Culturali" (from 1985 onwards); the review of conservation Arkos; the restoration periodical Kermes; IGIIC, the Italian Group of IIC, since 2003; and of course, the impressive editorial activity of the Opificio delle Pietre Dure and other restoration centres. Moreover, I should also mention documents of various sorts, and what one discerns in real interventions of conservation: what I mean, is that ideas and concepts can find many varied ways to enter theoretical debates. My second point is that clinging to theories is in my opinion respondent to the Italian tradition of favouring philosophical approaches to problems, from the Antiquity onwards; while the Anglo-Saxon tradition rather resorts to Ethics, as one reads in so many documents from professional associations and institutions. Not for nothing one has "Teorie del Restauro" on one side, Codes of Ethics on the other. I suspect that possibly this dichotomy has something to do with the differences between the Catholic and the Protestant tradition. Anyway, at the end, no matter what term we choose to apply, theory or practice, what is imperative is that the eventual result is determined by best practices, and maybe these will respond to the best theories.

Previously almost identical in: Toward a new definition of restauro, Theory and Practice in Conservation, Proceedings of the International Seminary (Lisbon 2006), J. Delgado Rodriguez and J.M.Mimoso Editors, Laboratório Nacional de Engenharia Civil, 2006, pp.7-13. 


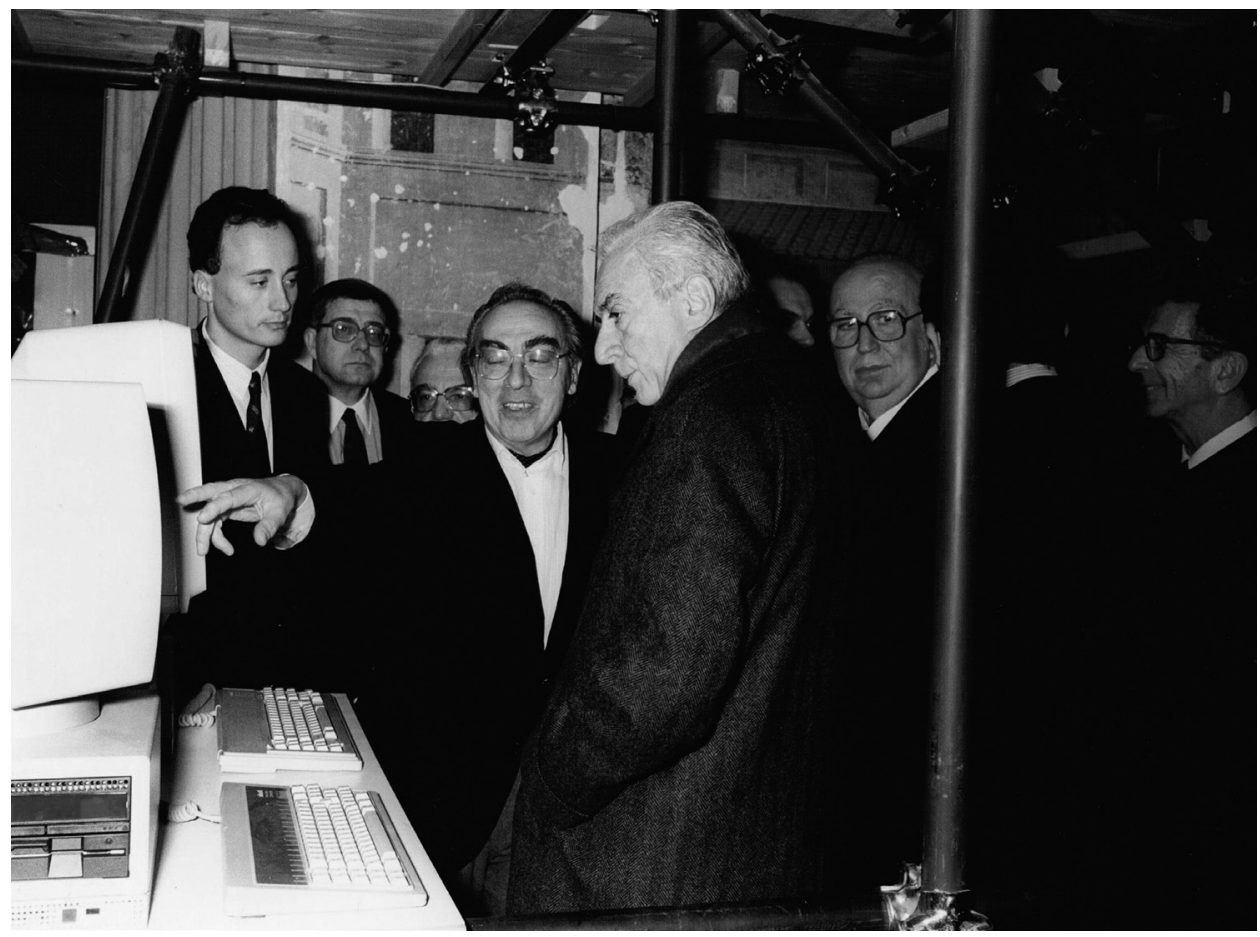

Fig. 1 Umberto Baldini with Francesco Cossiga President of the Italian Republic, Giovanni Spadolini President of the Italian Senate and former Prime Minister, Massimo Bogianckino Mayor of Florence (end of the 1980es)

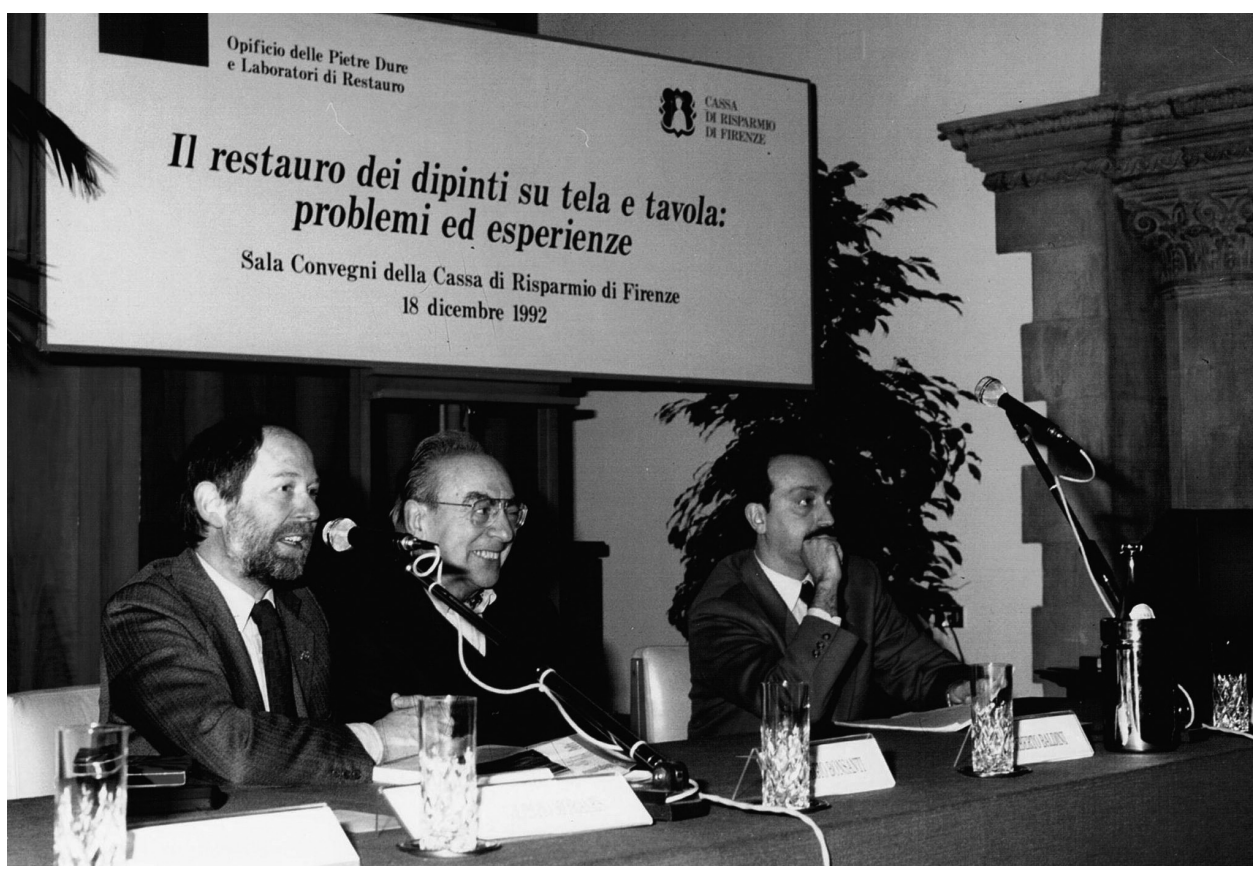

Fig. 2 Florence 1992: Giorgio Bonsanti, Umberto Baldini, Marco Ciatti 

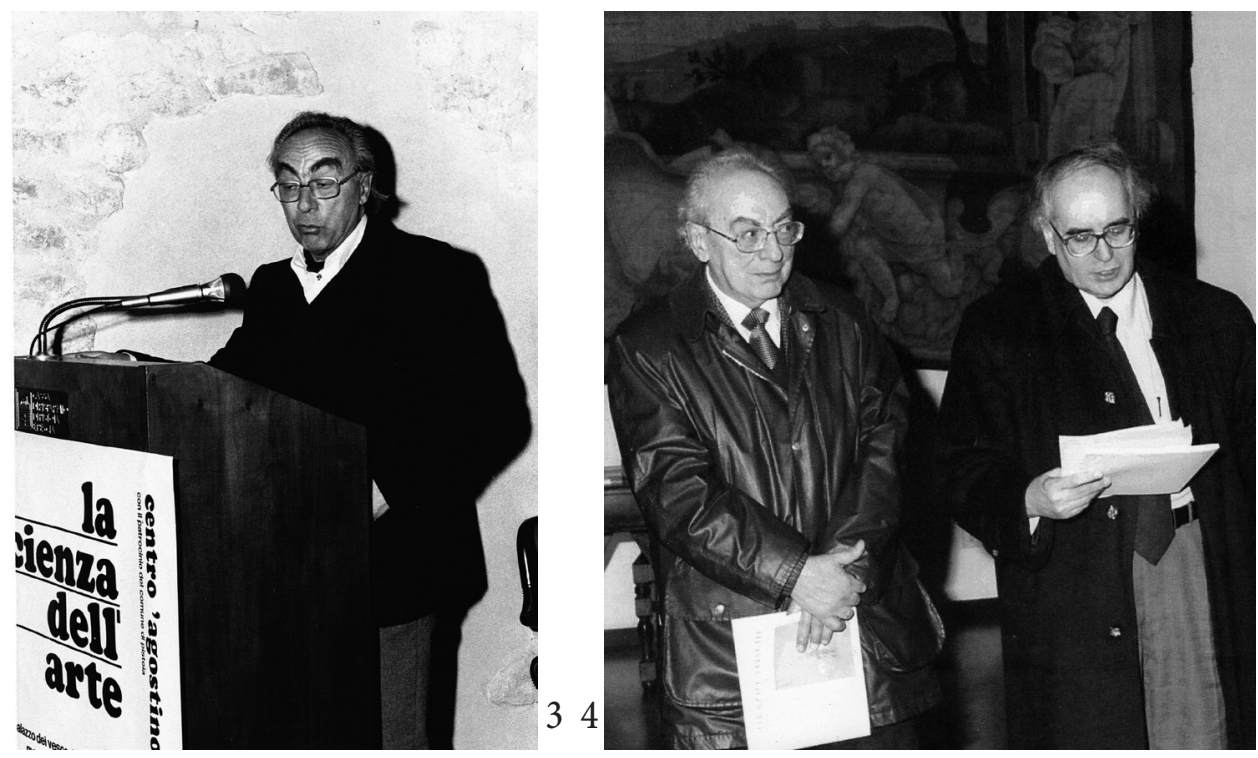

Fig. 3 Umberto Baldini

Fig. 4 Umberto Baldini with architect Francesco Gurrieri at the Accademia delle Arti del Disegno in Florence

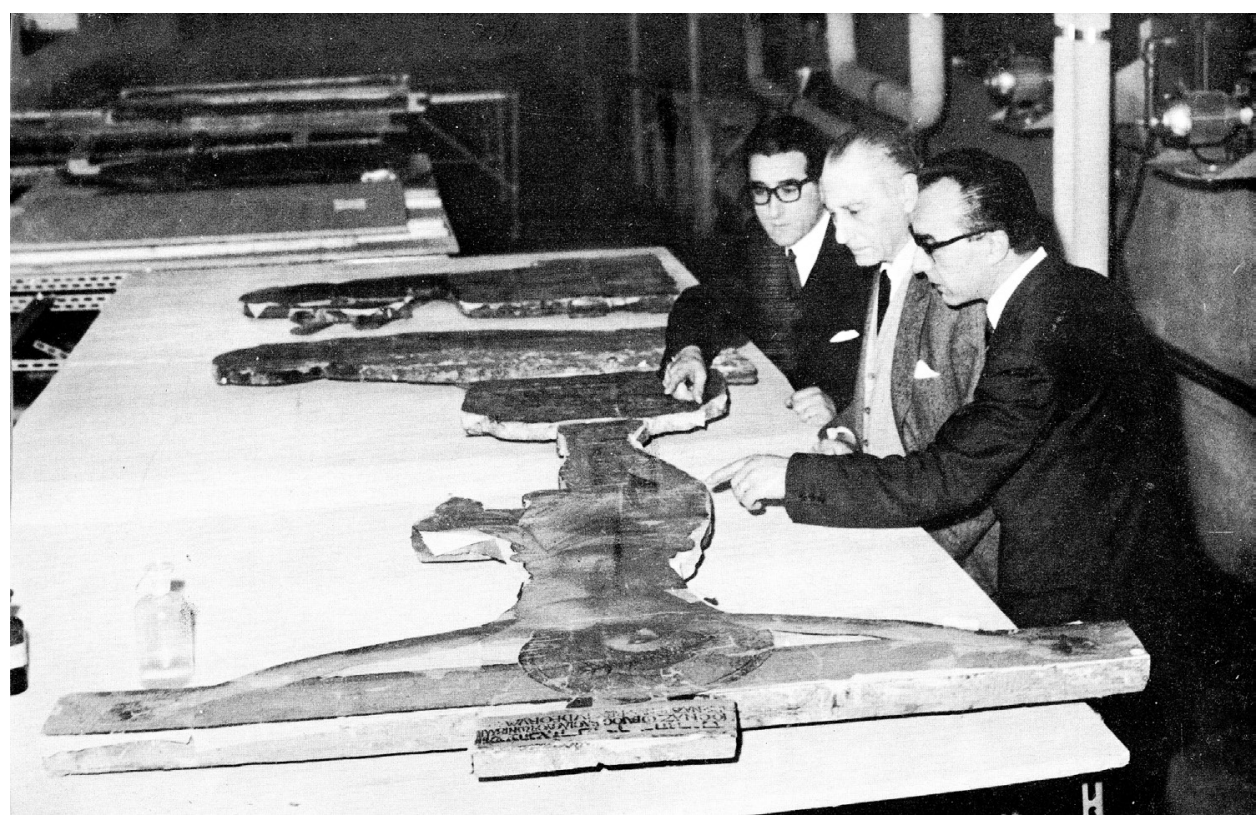

Fig. 5 After the flood (Florence 1966): the restorers Edo Masini, Gaetano Lo Vullo, and Umberto Baldini (c.ca 1970) 


\section{Bibliography}

Baldini, U. (1978). Teoria del restauro e unità di metodologia. Firenze: Nardini editore.

Baldini, U. (1981). Teoria del restauro e unità di metodologia, volume secondo. Firenze: Nardini editore.

Bonsanti, G. (2006). Per una definizione di restauro. In: Kermes, Aprile - Giugno 2006, n.62, pp. 67 - 71.

Bonsanti, G. (2013a). Baldini teorico del restauro. In: Il ruolo di Umberto Baldini per la conservazione del patrimonio culturale: una prospettiva storica (pp. 73-82). Atti della giornata di studi (Firenze, 14 dicembre 2011). Firenze: Edifir.

Bonsanti, G. (2013b). Giudizi o intuizioni. Un'attribuzione al Maestro dell'Altare di San Bartolomeo. In: Nezzo, M. \& Tomasella, G. (Eds.), Sotto la superficie visibile. Scritti in onore di Franco Bernabei (pp. 55-65). Treviso: Canova Edizioni.

Brandi, C. (1963). Teoria del restauro: lezioni raccolte da L. Vlad. Borrelli, J. Raspi Serra, G. Urbani ... Con una bibliografia generale dell'autore. Roma: Edizioni di Storia e letteratura.

Brandi, C. (1977). Teoria del restauro. Torino: Giulio Einaudi Editore - Piccola Biblioteca Einaudi Ns.

Brandi, C. (2005). Theory of Restoration. Edited by Giuseppe Basile and the Istituto Centrale per il Restauro, translated by Cynthia Rockwell. With presentations by Giuliano Urbani, Nicholas Stanley-Price, Caterina Bon Valsassina, with texts by Giuseppe Basile, Paul Philippot, Giulio Carlo Argan, Cesare Brandi. Firenze: Nardini editore.

Casazza, O. (1981). Il restauro pittorico nell'unità di Metodologia. Firenze: Nardini editore.

Ciatti, M. (2009). Appunti per un manuale di storia e di teoria del restauro - dispense per gli studenti, con la collaborazione di Francesca Martusciello, Firenze: Edifir.

Ciatti, M. \& Martusciello, F. (Eds.). (2013). Il ruolo di Umberto Baldini per la conservazione del patrimonio culturale: una prospettiva storica, Atti della giornata di studi (Firenze, 14 dicembre 2011). Firenze: Edifir.

Cordaro, M. (2009). Introduzione. In: Brandi, C. ([1994] 2009). Il Restauro - Teoria e pratica 1939 - 1986 (pp. 7 - 28). Roma: Editori Riuniti.

Lacuna. Riflessioni sulle esperienze dell'Opificio delle Pietre Dure (2009). Atti dei convegni del 7 aprile 2002 e del 5 aprile 2003 (Salone dellarte del Restauro e della conservazione dei Beni Culturali e ambientali, Ferrara), Firenze: Edifir.

Martusciello, F. (2013). Vita di Umberto Baldini. In: Il ruolo di Umberto Baldini per la conservazione del patrimonio culturale: una prospettiva storica (pp. 21 - 60). Atti della giornata di studi (Firenze, 14 dicembre 2011). Firenze: Edifir. 